THE POWER OF HUACAS 
THIS PAGE INTENTIONALLY LEFT BLANK 


\section{THE POWER OF HUACAS}

Change and Resistance in the Andean World of Colonial Peru

BY CLAUDIA BROSSEDER 
This book was produced with the help of the Deutsche

Forschungsgemeinschaft and Heidelberg University.

Copyright (C) 2014 by the University of Texas Press

All rights reserved

Printed in the United States of America

First edition, 2014

Requests for permission to reproduce material from this work should be sent to:

Permissions

University of Texas Press

P.O. Box 7819

Austin, TX 78713-7819

http://utpress.utexas.edu/index.php/rp-form

@ The paper used in this book meets the minimum requirements of ANSI/NISO Z39.48-1992 (R1997) (Permanence of Paper).

LIBRARY OF CONGRESS CATALOGING-IN-PUBLICATION DATA

Brosseder, Claudia, 1973-

The power of huacas : change and resistance in the Andean world of colonial Peru / by Claudia Brosseder. - First edition.

pages $\mathrm{cm}$

Includes bibliographical references and index.

ISBN 978-0-292-75694-6 (hardback)

1. Indians of South America-Peru-Religion. 2. Indians of South AmericaPeru-Rites and ceremonies. 3. Shamanism-Peru. 4. Peru-Religious life and customs. 5. Peru-History-1548-1820. I. Title.

F223O.1.R3B76 2014

$299.811^{\prime} 44-\mathrm{dc} 23$

2014002682

doi:10.7560/756946 